\title{
Review on Variants in Genes Associated with Cancer Risk and Red Meat Metabolism
}

\author{
Nurulhafizah Samsudin, Nurul Hanis Ramzi, Revathi Nagaretnam and Livy Alex
}

INFOVALLEY® Group of Companies, Unit 1.1, Level 1, Block B, MINES Waterfront Business Park, No. 3, Jalan Tasik, MINES Resort City, 43300 Selangor Malaysia

\begin{abstract}
With the advent of human genome sequencing project, came the wave of personalized genomics. Scientists have now gone beyond scanning of individual genes and epigenetic variations that might alter an individual's predisposition to developing complex diseases. Nutritional genomics is a science which is fast catching up. Efforts to explain the diet-gene interactions often recapitulate the effects of genetic makeup in determining the exact fate of the meal we ate last.

Diet-gene interactions play a major role in the metabolism and detoxification of food-derived mutagens and carcinogens. Heterocyclic amines (HCAs), polycyclic aromatic hydrocarbons (PAHs), and N-nitroso compounds (NOCs) are a class of mutagens or carcinogens found in red and processed meat that can lead to various types of cancers. Harboring unfavourable mutations or single nucleotide polymorphisms (SNPs) involved in metabolism of HCAs, PAHs, and NOCs can promote cancers. Increasing risks of several types of cancers, such as cancer of the colorectum, breast, prostate, esophagus, and lung, have been associated with high intake of red and processed meat. We attempt to compile some of the variants based on reports published during the past five years on variations involved in red meat metabolism which aims to provide useful insight in aiding us to regulate our red meat intake to avoid spurring of cancer.
\end{abstract}

Keywords: Red meat, processed meat, heterocyclic amines (HCAs), polycyclic aromatic hydrocarbons (PAHs), Nnitroso compounds (NOCs), cancers, xenobiotic metabolism.

\section{INTRODUCTION}

\section{Impact of Non-Genetic Factor on Cancer Development}

Initiation of cancer inside our body could be due to a number of internal and external factors that play important roles in either aggravating or slowing the cancer growth. Internal factors such as age, gender and genetic factors are uncontrollable but external factors can be controlled. External factors could include any non-genetic factors such as diets, lifestyle, and exposure to harmful substances. We exist in a polluted and contaminant-rich environment, making our genetic makeup persistently interacting with harmful external factors. For example, inorganic arsenic in drinking water, tobacco smoke, water chlorination by-products like chlorine, hypochlorite, chloramine, and chlorine dioxine, and lastly organic compounds like nitrites, nitrates, radionuclides and asbestos [1]. This may destabilize normal balances and regulations for cellular growth and maturation.

The National Cancer Institute $(\mathrm{NCl})$ claimed that nearly two in three cancer cases (67 percent) are associated with some type of environmental factors [2]. Another experimental data by Parkin et al. [3] found

*Address correspondence to this author at the INFOVALLEY® Group of Companies, Unit 1.1, Level 1, Block B, MINES Waterfront Business Park, No. 3, Jalan Tasik, MINES Resort City, 43300 Selangor Malaysia; Tel: (603) 8941 5830; Fax: (603) 8941 5970; E-mail: drlivys@yahoo.com that exposure to 14 specific external factors (tobacco, alcohol, meat, fruit, vegetables, fibers, salts, overweight, sedentary lifestyle, occupational hazards, infections, radiations, exogenous hormones, and reproductive history) was responsible for $42.7 \%$ of cancers.

How cancers are influenced by lifestyle and diet was made clear by a study on Japanese immigrants in the United States (US). Japanese men born in the US have twice the rate of colon cancer as their counterparts born in foreign countries. Similarly, the rate of colon cancer in Japanese women born in US is 40 percent higher than in the native-born women [4]. Oncogenesis is often multi-factorial. This study demonstrates that besides genetic make-up, environment also plays an important role in colon cancer development.

Nevertheless, major external factors associated with cancer development can be avoided by having good lifestyle choices. Indeed, almost one-third of cancers are preventable for example by eliminating the use of tobacco products, eradication or vaccination against cancer-related infectious agents [Human papillomavirus (HPV), Epstein Barr virus (EBV), and Helicobacter pylori], increasing fruits and vegetables consumptions to at least five servings per day, and avoiding hazardous environmental chemicals like air pollutants [5]. 
Table 1: Common Additives Used in Processing Meat

\begin{tabular}{|c|c|}
\hline Ingredient & Functionality \\
\hline \hline Salt & Taste and shelf life \\
\hline Nitrite/nitrate & Curing color, flavor, and shelf life \\
\hline Ascorbic acid & Accelerate curing \\
\hline Phosphates & Water binding and protein hydration \\
\hline Erythorbate & Accelerate curing \\
\hline Sweeteners (sucrose, dextrose, corn syrup, honey, sorbitol, lactose) & Surface browning and sweetening agents \\
\hline Seasonings (spices, herbs, vegetables, essential oils) & Flavor, color \\
\hline Acidifiers (lactic acid, citric acid) & Tangy/tart flavor, shelf-life, tenderize meat \\
\hline
\end{tabular}

(Source: Encyclopedia of Meat Sciences).

\section{Dietary Factors as Cancer Causes}

The pertinence of unhealthy diet in increasing cancer risks has been demonstrated in cancer of gastric, colon, rectum, lung, breast, and prostate [6]. Consumption of a lot of fibers, fish, fruits, vegetables and little of red meat, processed meat, alcohol, saturated fat, calcium from dairy products help reduce cancer risks $[3,6]$.

Interestingly, among all dietary factors, meat shows strong positive associations with cancer development. Three categories of meat are red meat, processed meat, and white meat. Gastronomically, red meat is darker-colored meat from cows, sheep, horses, pigs, ducks and geese. Foods like steak, pork chops and roast lamb contain red meat. Processed meat refers to meat treated by smoking, curing, salting or by the addition of preservatives for longer-term preservation. Examples include ham, bacon, pastrami, salami, hot dogs and sausages. White meat is lighter-colored meat of poultry. Every so often young milk-fed calves, sheep and pigs are considered white.

The processed meats have been linked to increasing risk of cancer, cardiovascular disease, and early deaths according to a study on half a million Europeans by Rohmann et al. [7]. Its harmful effects appear as the results of physical and chemical treatments it has undergone such as dry-curing, smoking, and brining. Some of the common additives in the dry-curing, smoking, and brining are shown in Table 1. Dry-curing process allows meat dehydration which creates a less favorable environment for microorganisms to grow. Another technique called brining involves the process of submerging or injecting red meat with salt water solution (Figure 1). It preserves and increases water content in red meat, resulting in juicy and flavorful meat once cooked. Smoking is one of a preservation methods where it exposes meat to fume from smoldering fire over a period of time. Air and smoke drawn in through an opening allow bactericidal and anti-oxidative properties to penetrate into the meat [8]. Different temperature is used in different smoking techniques such as hot smoking $\left(50-85^{\circ} \mathrm{C}\right)$, warm smoking $\left(25-50^{\circ} \mathrm{C}\right)$, and cold smoking $\left(12-25^{\circ} \mathrm{C}\right)$ [9]. Green or wet alder, apple, cherry, maple, oak, or pecan woods cause fire to rekindle and add specific flavor to the meat. Following smoking treatment, the moisture in red meat drops about 10 to $40 \%$ [9].

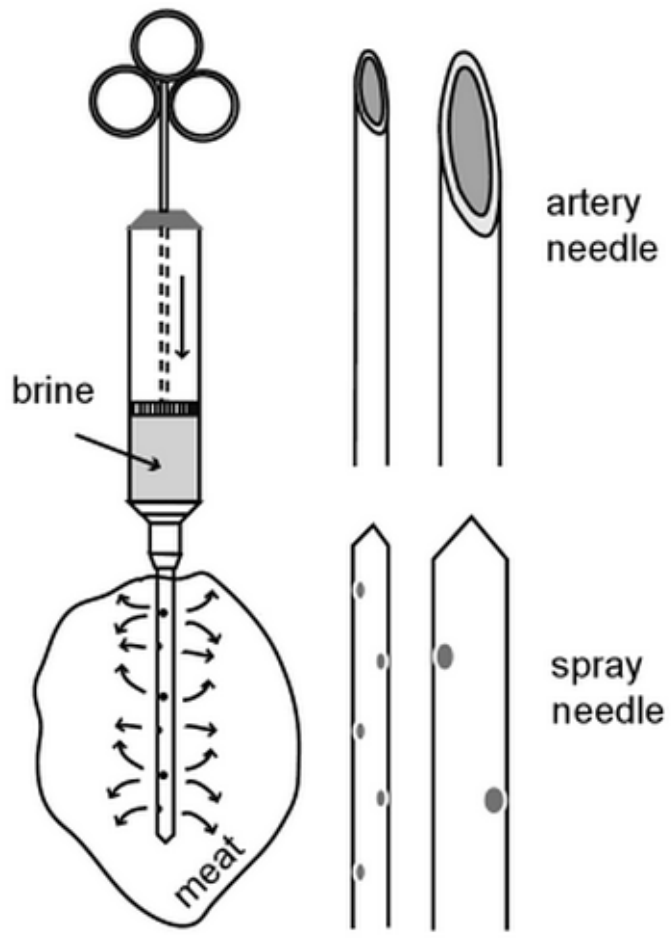

Figure 1: In brining, meat is injected with salt water using specialized needles such as artery or spray needle to increase the meat's juiciness (Source Marianski et al. [75]). 


\section{Mutagenic and Carcinogenic Aspects of Red and Processed Meat}

Meat is a good source of protein, iron, and minerals such as zinc, phosphorus, and B-vitamins. It is also the richest source of alpha lipoic acid, which is a powerful antioxidant. However, the processing and cooking of red meat may produce mutagenic compounds that may promote cancer development. Although red meat is rich in nutrients, people are advised to opt for leaner cuts and healthier meat products while cutting down on processed meat.

Heterocyclic amines (HCAs) can be found in smoked, grilled, fried, and barbecued meat. HCAs form when amino acids react with creatine when meat is cooked at high temperature for extended time [10]. Three primary dietary HCAs are 2-amino-1-methyl-6phenylimidazo[4,5-b]pyridine (PhIP), 2-amino-3,8dimethylimidazo[4,5-f]quinoxaline (MelQx), and 2amino-3,4,8-dimethylimidazo[4,5-f]quinoxaline

(DiMelQx). These mutagenic compounds when activated by cytochrome P450 1A2 (CYP1A2) and Nacetyltransferase-2 (NAT2) may damage DNA and increase the risk of tumorigenesis [11]. Polymorphisms within CYP1A2 and NAT2 may interrupt the metabolism and detoxification of HCAs. However, the mutagenicity of the compounds can be reduced by high intakes of fruits, vegetables, or cereals at the same time [10].

Polycylic aromatic hydrocarbons (PAHs) are organic compounds that are able to bind covalently to macromolecules including DNA. The binding of these compounds to DNA has been proven carcinogenic in animal studies since it results in erroneous DNA replication and mutation [12]. PAHs form in pyrolytic process, especially during incomplete combustion of organic matter in the cooking and smoking or red meat. Benzo[a]pyrene and benz[a]anthracene, the most commonly known PAHs, are possibly carcinogenic and mutagenic to human [13].

$\mathrm{N}$-nitrosation is a process that converts peptidederived amines or amides into $\mathrm{N}$-nitroso compounds (NOC) [14]. NOC are cytotoxic and mutagenic. During metabolism, NOC can yield alkylating adducts like alkyl carbon groups that can bind to biological molecules and alter their functions and structures [15]. Red and processed meat has abundant presence of heme-iron that has catalytic effect on the formation of NOC and aldehydes that are toxic to cells [14]. Ingestion of heme-iron from red meat has been shown to increase the formation of carcinogenic NOC in human [16].

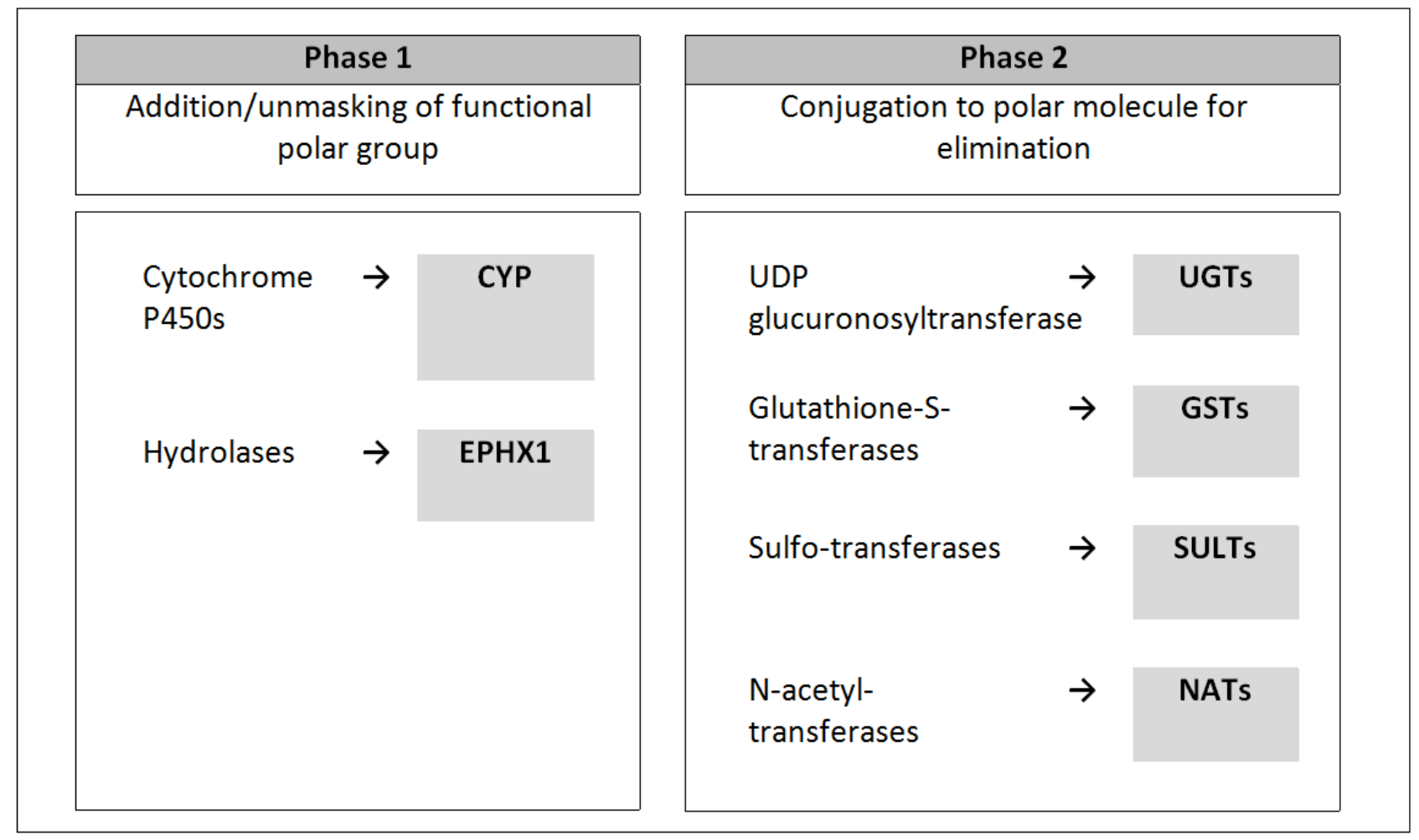

Figure 2: Major enzymes in xenobiotic metabolism pathway.The major xenobiotic metabolism enzymes (XMEs) in Phase I such as CYP and EPHX1 are involved in functionalization or activation. XMEs in Phase II like UGTs and NATs have important roles in the conjugation to polar molecule for elimination. 
Exposure to endogenous NOC and aldehydes may lead to DNA damages. The accumulation of defective genetic materials may consequently contribute to cancer etiology.

\section{GENETIC VARIATIONS ASSOCIATED WITH RED MEAT}

\section{Role of Xenobiotic Metabolism Pathway}

Xenobiotic metabolism is postulated to be the major pathway for detoxification of chemicals not normally present in an organism. However, in certain events, the metabolism of xenobiotic compounds may produce reactive or carcinogenic intermediates that are harmful to the cells. HCAs, PAHs and NOCs are meat-derived procarcinogenic agents that require metabolic activation and conjugation by wide range of xenobiotic metabolism enzymes (XMEs) of Phase I and II to turn into genotoxic-carcinogens [17, 18]. Genotoxic carcinogens are agents capable of inducing DNA lesions.

Figure 2 illustrates some of the major enzymes involved in Phase I and II of xenobiotic metabolism pathway. Cytochrome P450 (CYP) isoforms are the main activating enzymes comprising of $70-80 \%$ of phase I XMEs [19]. Most phase I XMEs are capable of both detoxification and metabolic activation. The metabolic activation of procarcinogens often leads to formation of electrophilic intermediates. Conjugation enzymes like uridine diphosphate glucuronosyltransferase (UGTs), glutathione S-transferases (GSTs), sulfotransferases (SULTs) as well as $\mathrm{N}$-acetyltransferases (NATs) are among the phase II XMEs.

The chemical structure and the functional groups of various XMEs substrates are relatively important. For example, PAHs are very hydrophobic and these procarcinogens are substrates for the CYP1 enzymes (CYP1A1, CYP1A2 and CYP1B1) [20]. The activation and detoxification of a carcinogen will depend on the amount, activity, and presence of XMEs in the tissue [21]. Thus, XME genes show a high level of timespecific, organ specific, tissue specific and cell-typespecific expression.

The CYP enzymes especially CYP1, CYP2, CYP3 and CYP4 gene families show some redundancy and overlapping substrate specificity. Depending on the predominance of one or another enzyme, the metabolic spectrum changes depending on the environment to the development of cancer. Other enzymes in CYP gene families control the levels of sex steroids, corticosteroids, cholesterol, bile acids and morphogens such as retinoic acid; because these endogenous substrates are sometimes associated with tumour promotion, it might be concluded that these CYP enzymes participate indirectly in tumorigenesis [22].

\section{Genetic Polymorphisms of Xenobiotic Metabolizing Genes}

Variation in genes that encode XMEs are hypothesized to alter enzyme expression and function, resulting in differential metabolism of xenobiotics among individuals [23]. Such variants which include changes in nucleotide bases known as single nucleotide polymorphisms (SNPs) within genome are responsible for many of the phenotypic characteristics. It is believed that there are up to 53 million SNPs in the human genome, as they occur once in every 300 nucleotides on average [24]. Past and current examples of a few extensively studied SNPs include those in the genes encoding for GSTs, NATs, and the CYP isoenzymes. Many genetic variants in the CYP families have been widely identified and studied due to the role of CYP isoenzymes in metabolizing a large number of structurally diverse drugs and chemicals.

Many allelic variants of human CYP1, CYP2, CYP3 and CYP4 genes exist, resulting in possible alterations in metabolism of xenobiotic compounds. The Human Cytochrome P450 (CYP) Allele Nomenclature Database (http://www.cypalleles.ki.se/) depicts various identified genetic variants of CYP1A1, of which CYP1A1*2B, *2C, *4, *5, *6, *7, *8, *9, *11 show amino acid changes. In addition, Saito et al. [25] has identified four nonsynonymous variants of $\mathrm{CYP} 1 \mathrm{~A} 1{ }^{*} 7$, $\mathrm{CYP} 1 \mathrm{~A} 1{ }^{*} 8, \mathrm{CYP} 1 \mathrm{~A} 1{ }^{*} 9$ and $\mathrm{CYP} 1 \mathrm{~A} 1{ }^{*} 10$ that are closely linked in the heme-binding region in the Japanese population. These four genetic variants are presumed to have roles in generating premature stop codon and altering CYP1A1 catalytic activity in metabolizing HCAs, PAHs and other xenobiotic compounds.

Studies by Inoue et al. [26] suggest that ethnicrelated differences exist in the genetic variance of CYP1A1 and CYP1B1 genes. The study that was done on Japanese and Caucasian population provides possible explanation for the differences in cancer occurrence rate among ethnicities [26]. Interestingly, a study by Zhu et al. [27] on African American population revealed that dietary factors including low intakes of folate, methionine, vitamin $\mathrm{C}$, and vitamin $\mathrm{E}$ may contribute to increased risk of breast cancer in 
individuals inheriting African-American-specific polymorphism within the CYP1A1 gene.

Most investigations on cancer risk arising from CYP1A1 polymorphism have studied the effects of modified CYP1A1 in association with deficient phase II XMEs (predominantly GST) and other genetic variants that affect activation and detoxification of CYP1A1 substrates [28]. A cross-sectional study by Moreti et al. [29] published results of genetic polymorphisms for CYP1A1, EPHX (epoxide hydrolase), and GSTM1 genes that revealed the influence of primary DNA damage in $\mathrm{PAH}$-exposed workers.

Supplementary Table 1 summarizes some of the polymorphic variations in the xenobiotic metabolizing genes that may play role in cancers susceptibility. In general, there is little consensus in the literature for $\mathrm{XME}$ gene-meat interactions in relation to cancer susceptibility for CYP1A1, CYP1A2, CYP1B1 [18, 3032], CYP2E1 [18, 30, 31], EPHX1 [18, 30, 32-34], NAT1 and NAT2 [18, 30, 32, 35, 36] or SULT1A1 [30, 35] phenotypes. In addition, there are limited data on AMACR [37], SULT2A1 [33] and RAPTOR [38].

\section{RED MEAT AND CANCER RISKS}

\section{Colorectal Cancer}

The World Cancer Research Fund (WCRF) declared that high red meat intake could significantly increase the risk of colorectal cancer [39]. The association between red meat consumption and colorectal cancer has been studied extensively over a wide range of populations. Findings from a large prospective cohort study on US population, support the positive association between consumption of red or processed meat and colorectal cancer [40]. In the Uruguay populations, significant supportive evidences have also linked red and processed meat with colorectal cancer [41, 42].

Albeit, the limited studies on Eastern populations have shown inconsistence results. For instance, in Japanese populations, only red meat intake has been modestly associated with colon cancer; no association with processed meat was found [43]. Significant association between red meat and colorectal cancer risk was also found in Shanghai Chinese men; however, the processed meat was not assessed quantitatively due to the very low intake in their culture [44].
These inconsistencies may be explained by the fact that the molecular makeup of colorectal cancers of the Eastern populations tend to differ from the West [45, 46]. Colorectal cancers can be classified into four molecular subtypes, each with uniquely global genomic and epigenomic aberrations influenced by microsatellite instability (MSI) and $\mathrm{CpG}$ island methylator (CIMP) [46]. Previous studies demonstrate that the prevalence of $\mathrm{CIMP}+\mathrm{MSI}+$ subtype versus CIMP-/MSI+ subtype is distinctly different between the Eastern and the Western populations [45, 46].

In addition, Eastern populations in general consume less meat compared to the west $[43,44]$. According to WCRF, avoiding processed meat and limiting consumption of red meat to less than $500 \mathrm{~g}$ per week may attribute to decreased risk for colorectal cancer [39]. However, more studies on Asian populations are needed to confirm these associations.

Processed meat show stronger association with colorectal cancer compared to unprocessed meat [47]. Although the biological mechanism is still uncertain, harmful compounds such as heme-iron, $\mathrm{N}$-nitroso compounds, HCAs, MelQx, and DiMelQx, added or produced during the processing steps have been significantly associated with increased risk of colorectal cancer [40]. Vitamin $C$ and $E$, which are replenished in fruits and vegetables, inhibit the formation of NOC, thus, reducing the risk of developing colorectal cancer (Figure 3).

Certain genetic polymorphisms may significantly alter the risk of colorectal cancer with relation to red meat consumption. For instance, -154A>C (CYP1A2) has been found to modify colorectal cancer risks associated with high consumption of well-done red meat cooked at high temperature [32]. Furthermore, along with red meat intake of more than three servings per week, individual with Val762Ala (PARP) has shown to have significant increase in colorectal cancer risk [48]. Daily increase of $100 \mathrm{~g}$ red meat may lead to 12 $17 \%$ higher risk of developing colorectal cancer and a daily increase of $25 \mathrm{~g}$ processed meat increases the risk to $49 \%$ [49]. Boosting intakes of protective diets like vegetables, fruits, and supplements and limiting red meat intake may keep the risks at low even for individuals with genetic risks.

\section{Other Cancers}

Evidences show that high intake of red or processed meat may also modify the risks of breast, prostate, esophageal, and lung cancer [41, 50-63]. 


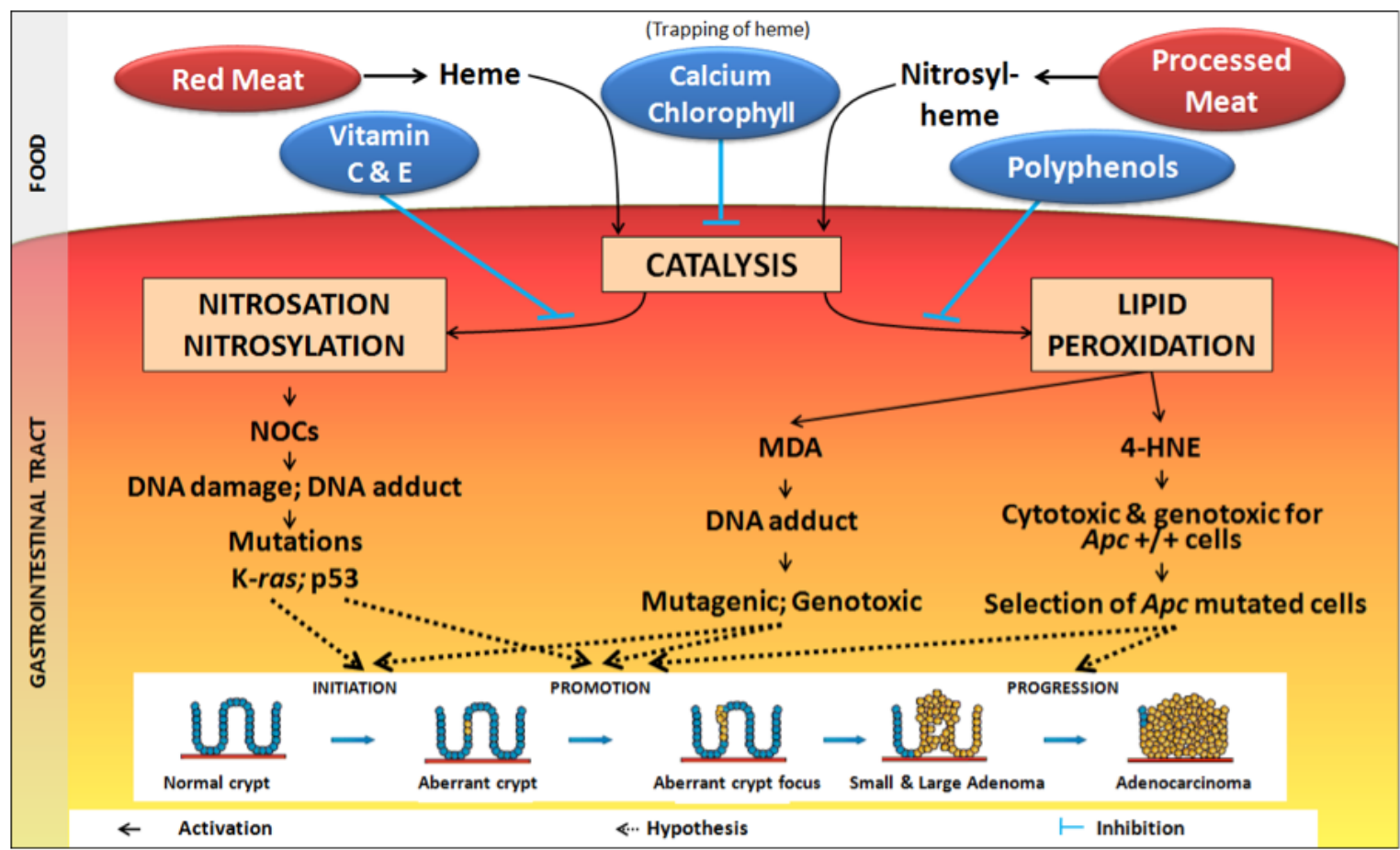

Figure 3: Catalytic effects of nitrosation from red and cured meat on the development of colorectal cancer. Heme iron catalyzes N-nitroso compounds (NOCs) formation and lipid peroxidation which are mutagenic and may have role in the development of colorectal cancer.

Adapted from Bastide et al. 2011.

Studies on breast cancer focus mainly on the premenopausal and postmenopausal status. For instance, premenopausal breast cancer was positively associated with high red meat consumption (OR=2.20, $95 \% \mathrm{Cl} 1.35-3.60)$ [53]. In another study involving approximately 4000 women from US, stronger associations between red meat and breast cancer were also found in postmenopausal women compared to premenopausal women [51]. Dietary iron derived from meat and meat mutagens like HCAs, MelQx, and DiMelQx produced during high-temperature cooking have been significantly associated with postmenopausal breast cancer [50, 51]. In addition, consumption of red meat from cattle administered with exogenous hormones to increase muscle mass or milk production may be one of the reasons that trigger the development of hormone-sensitive breast cancers [64].

Aggressive prostate cancer has been positively associated with high consumption of ground beef, processed meat, and well-done grilled or barbecued red meat [54]. Supportive evidences by John et al. [55] also show that high intake of processed meat or red meat cooked at high temperature may also increase the risk of advanced prostate cancer. Prostate cancer is an extremely heterogeneous disease. It may be indolent in some but more aggressive in others. In metastatic and hormone-refractory prostate cancers, amethylacyl-CoA racemase (AMACR) was found to be strongly upregulated [65]. Interestingly, the AMACR enzyme also plays important role in the regulation of peroxisomal beta-oxidation of phytol-derived, branched-chain fatty acids from red meat and dairy products [66].

The risk of esophageal squamous cell carcinoma, a subtype of esophageal cancer, increases with high intake of red and processed meat $[58,59]$. In addition, an increased risk of esophageal adenocarcinoma, which is a cancer that originates from glandular tissue, has been linked to high consumptions of processed meat [60]. Heme-iron and MelQx or PhIP (HCAs) have been significantly associated with increased risk of esophageal carcinoma [59]. These mutagens derived from meat may contribute to the increased formation of free radicals and oxidative stress in the esophageal tissues, eventually causing chronic inflammation and cancer development in the esophagus.

Lung cancer has also been associated with high intake of fried meat, barbecued meat, and salted meat [61]. By far, smoking is the major risk factor for lung cancer. Approximately $80 \%$ of lung cancers are caused by cigarette smoking worldwide [39]. Interestingly, several evidences have linked red and processed meat 
with increased risk of lung cancer among neversmokers [62, 63].

Positive associations with red meat intake have also been found in cancer of the bladder, pancreas, endometrium, head and neck, upper aerodigestive tract, larynx, oral and pharynx [36, 67-72]. However the studies are still very limited and require further investigation. The associations between meat-based dietary factors and cancers are shown in Supplementary Table 2.

\section{PREVENTIVE MEASURES}

Healthier meat products with reduced contents of fat, calories, cholesterol, and salt can be taken as an alternative. As much as $35 \%$ of fat content in beef frankfurters is reduced by replacing $60 \%$ of the beef fat with vegetable oil [73]. Nitrosation depends on the residual nitrite level. Thus far, no alternative has been found for nitrite. However, by reducing salt content, we may also reduce the carcinogenic $\mathrm{N}$-nitrosamine formation.

Fibers are found abundantly in protective diets like fruits and vegetables. Intakes of food loaded with fibers increase stool bulk and speeds the food movement through the colon. This helps reduce the absorption and contact time with the potential carcinogens.

Supplementary calcium may have preventive action against cancer progression. Calcium phosphate has the ability to precipitate heme, thus inhibiting hemeinduced cytotoxicity [14]. In an animal model, dietary calcium has shown to inhibit chemically-induced carcinogenesis, diet-induced epithelial hyperproliferation and recurrence of colorectal adenoma [74].

\section{CONCLUSION}

Cancer development is the result of complex interplay between genetic and environmental factors. It is essential that ones's personal environment is well controlled and managed by the individual. Limiting red and processed meat helps reduce the risks of developing various types of cancers. As recommended by the WCRF, avoiding processed meat and limiting red meat intake to less than $500 \mathrm{~g}$ per week can reduce the risk of developing cancers.

HCAs, PAHs and NOCs are considered procarcinogenic agents found in red meat. They are metabolized by the Phase I and II of the XMEs. However, the XMEs may also induce HCAs, PAHs, and certain NOCs to fully attain their carcinogenic potentials. SNPs in the genes that encode XMEs play a critical role in influencing the risk susceptibility of individuals to different cancers.

This review shows that a large number of variants have been discovered in the xenobiotic enzymes leading to differences in metabolism of these carcinogens. The genetic make-up cannot be altered but the hope resides in the fact that one can take preventive measures like reducing red and processed meat intake and taking a good amount of protective diets like fruits and vegetables.

\section{ABBREVIATIONS AND ACRONYMS}

$\begin{array}{ll}\text { AMACR } & =\text { a-methylacyl-CoA racemase } \\ \text { CIMP } & =\text { CpG island methylator } \\ \text { CIN } & =\text { Chromosomal instability } \\ \text { CYP } & =\text { Cytochrome P450 } \\ \text { DiMeIQx } & =2 \text {-amino-3,4,8-trimethylimidazo[4,5- } \\ \text { EPHX } & =\text { Epouinoxaline } \\ \text { GSTM1 } & =\text { Glutathione S-transferase Mu 1 } \\ \text { GSTs } & =\text { Glutathione S-transferases } \\ \text { HCAs } & =\text { Heterocyclic amines } \\ \text { MDR1 } & =\text { Multidrug Resistance 1 } \\ \text { MelQx } & =2 \text {-amino-3,8-dimethylimidazo[4,5- } \\ & \text { f]quinoxaline } \\ \text { MSI } & =\text { Microsatellite instability } \\ \text { NATs } & =\text { N-acetyltransferases } \\ \text { PAHs } & =\text { Polycyclic aromatic hydrocarbons } \\ \text { PARP } & =\text { Poly (ADP-ribose) polymerase } \\ \text { PhIP } & =2 \text {-amino-1-methyl-6-pheylimidazo(4,5- } \\ & \text { b)pyridine }\end{array}$

RAPTOR = Regulatory associated protein of MTOR, complex 1

SNPS $=$ Single nucleotide polymorphisms

SULTS $=$ Sulfotransferases 
UGTs $=\begin{aligned} & \text { Uridine diphosphate } \\ & \text { glucuronosyltransferase }\end{aligned}$

WCRF $=$ World Cancer Research Fund

XMEs $=$ Xenobiotic metabolism enzymes

\section{ACKNOWLEDGEMENT}

We would like to acknowledge the Management of INFOVALLEY ${ }^{\circledR}$ Group of Companies, specifically the INFOVALLEY ${ }^{\circledR}$ Life Sciences Sdn. Bhd., for their generous support rendered to help publish this report.

\section{SUPPLEMENTAL MATERIALS}

The supplemental materials can be downloaded from the journal website along with the article.

\section{REFERENCES}

[1] Bofetta $P$, Nyberg F. Contribution of environmental factors to cancer risk. Br Med Bull 2003; 68: 71-94. http://dx.doi.org/10.1093/bmp/ldg023

[2] Cancer and the Environment - National Cancer Institute [Internet]. [cited 2013 Apr 9]. Available from: http: //www.cancer.gov/cancertopics/understandingcancer/environ ment/AllPages

[3] Parkin DM, Boyd L, Walker LC. The fraction of cancer attributable to lifestyle and environmental factors in the UK in 2010. Br J Cancer 2011; 105(Suppl) S77-81.

[4] Flood DM, Weiss NS, Cook LS, Emerson JC, Schwartz SM, Potter JD. Colorectal cancer incidence in Asian migrants to the United States and their descendants. Cancer Causes Control: CCC 2000; 11(5): 403-11. http://dx.doi.org/10.1023/A:1008955722425

[5] Alwan A. Noncommunicable diseases: a major challenge to public health in the region: editorial / Ala'din Alwan.

[6] Gonzalez CA, Riboli E. Diet and cancer prevention: Contributions from the European Prospective Investigation into Cancer and Nutrition (EPIC) study. Eur JCancer (Oxford, England: 1990) 2010; 46(14): 2555-62.

[7] Rohrmann S, Overvad K, Bueno-de-Mesquita HB, Jakobsen $\mathrm{MU}$, Egeberg R, Tjonneland $\mathrm{A}$, et al. Meat consumption and mortality - results from the European Prospective Investigation into Cancer and Nutrition. BMC Med 2013; 11(1): 63. http://dx.doi.org/10.1186/1741-7015-11-63

[8] Park, Lue, Ed. The Smoked-Foods Cookbook: How to Flavor, Cure, and Prepare Savory Meats, Game, Fish, Nuts, and Cheese (Google eBook). Stackpole Books 1992; p. 216.

[9] Schieberle HBWGP. Food Chemistry (Google eBook). Springer 2009; p. 1070.

[10] Ferguson LR. Meat and cancer. Meat Sci 2010; 84(2): 30813.

http://dx.doi.org/10.1016/j.meatsci.2009.06.032

[11] Voutsinas J, Wilkens LR, Franke A, Vogt TM, Yokochi LA, Decker $\mathrm{R}$, et al. Heterocyclic amine intake, smoking, cytochrome P450 1A2 and N-acetylation phenotypes, and risk of colorectal adenoma in a multiethnic population. Gut 2013; 62(3): 416-22. http://dx.doi.org/10.1136/gutjnl-2011-300665

[12] Falcó G, Domingo JL, Llobet JM, Teixidó A, Casas C, Müller L. Polycyclic aromatic hydrocarbons in foods: human exposure through the diet in Catalonia, Spain. J Food Prot 2003; 66(12): 2325-31.

[13] Polynuclear aromatic compounds, Part 1, Chemical, environmental and experimental data. IARC monographs on the evaluation of the carcinogenic risk of chemicals to humans 1983; 32: 1-453.

[14] Bastide NM, Pierre FHF, Corpet DE. Heme iron from meat and risk of colorectal cancer: a meta-analysis and a review of the mechanisms involved. Cancer Prev Res (Philadelphia, Pa.) 2011; 4(2): 177-84 http://dx.doi.org/10.1158/1940-6207.CAPR-10-0113

[15] Fu D, Calvo JA, Samson LD. Balancing repair and tolerance of DNA damage caused by alkylating agents. Nature reviews. Cancer 2012; 12(2): 104-20.

[16] Lunn JC, Kuhnle G, Mai V, Frankenfeld C, Shuker DEG, Glen RC, et al. The effect of haem in red and processed meat on the endogenous formation of $\mathrm{N}$-nitroso compounds in the upper gastrointestinal tract. Carcinogenesis 2007; 28(3): 685-90.

http://dx.doi.org/10.1093/carcin/bgl192

[17] Belitsky GA, Yakubovskaya MG. Genetic polymorphism and variability of chemical carcinogenesis. Biochemistry 2008 73(5): 543-54.

[18] Ferrucci LM, Cross AJ, Gunter MJ, Ahn J, Mayne ST, Ma X et al. Xenobiotic metabolizing genes, meat-related exposures, and risk of advanced colorectal adenoma. J Nutrigenet Nutrigenomics 2010; 3(4-6): 170-81. http://dx.doi.org/10.1159/000324351

[19] Evans WE, Relling MV. Pharmacogenomics: translating functional genomics into rational therapeutics. Science (New York, N.Y.) 1999; 286(5439): 487-91.

http://dx.doi.org/10.1126/science.286.5439.487

[20] Nelson DR. Cytochrome P450 and the individuality of species. Arch Biochem Biophys 1999; 369(1): 1-10.

http://dx.doi.org/10.1006/abbi.1999.1352

[21] Smith TJ, Liao A, Wang LD, Yang GY, Starcic S, Philbert $\mathrm{MA}$, et al. Characterization of xenobiotic-metabolizing enzymes and nitrosamine metabolism in the human esophagus. Carcinogenesis 1998; 19(4): 667-72. http://dx.doi.org/10.1093/carcin/19.4.667

[22] Nebert DW, Dalton TP. The role of cytochrome P450 enzymes in endogenous signalling pathways and environmental carcinogenesis. Nat Rev Cancer 2006; 6(12): 947-60. http://dx.doi.org/10.1038/nrc2015

[23] Shimada T. Xenobiotic-metabolizing enzymes involved in activation and detoxification of carcinogenic polycyclic aromatic hydrocarbons. Drug Metab Pharmacokinet 2006; 21(4): 257-76. http://dx.doi.org/10.2133/dmpk.21.257

[24] What are single nucleotide polymorphisms (SNPs)? US National Library of Medicine, National Institutes of Health, Department of Health \& Human Services 2013.

[25] Saito T, Egashira M, Kiyotani K, Fujieda M, Yamazaki H, Kiyohara $\mathrm{C}$, et al. Novel nonsynonymous polymorphisms of the CYP1A1 gene in Japanese. Drug Metab Pharmacokinet 2003; 18(3): 218-21. http://dx.doi.org/10.2133/dmpk.18.218

[26] Inoue K, Asao T, Shimada T. Ethnic-related differences in the frequency distribution of genetic polymorphisms in the CYP1A1 and CYP1B1 genes in Japanese and Caucasian populations. Xenobiotica; the fate of foreign compounds in biological systems 2000; 30(3): 285-95.

[27] Zhu K, Hunter S, Payne-Wilks K, Sutcliffe C, Bentley C, Roland $\mathrm{CL}$, et al. Potential differences in breast cancer risk factors based on CYP1A1 Mspl and African-Americanspecific genotypes. Ethn Dis 2006; 16(1): 207-15.

[28] Little J, Sharp L, Masson LF, Brockton NT, Cotton SC, Haites $\mathrm{NE}$, et al. Colorectal cancer and genetic polymorphisms of 
CYP1A1, GSTM1 and GSTT1: a case-control study in the Grampian region of Scotland. Int J Cancer 2006; 119(9): 2155-64.

http://dx.doi.org/10.1002/ijc.22093

[29] Moretti M, Dell'Omo M, Villarini M, Pastorelli R, Muzi G, Airoldi L, et al. Primary DNA damage and genetic polymorphisms for CYP1A1, EPHX and GSTM1 in workers at a graphite electrode manufacturing plant. BMC public health. 2007; 7: 270

http://dx.doi.org/10.1186/1471-2458-7-270

[30] Cotterchio M, Boucher BA, Manno M, Gallinger S, Okey AB, Harper PA. Red meat intake, doneness, polymorphisms in genes that encode carcinogen-metabolizing enzymes, and colorectal cancer risk. Cancer Epidemiol Biomarkers Prev 2008; 17(11): 3098-107. http://dx.doi.org/10.1158/1055-9965.EPI-08-0341

[31] Küry S, Buecher B, Robiou-du-Pont S, Scoul C, Sébille V, Colman $\mathrm{H}$, et al. Combinations of cytochrome P450 gene polymorphisms enhancing the risk for sporadic colorectal cancer related to red meat consumption. Cancer Epidemiol Biomarkers Prev 2007; 16(7): 1460-7. http://dx.doi.org/10.1158/1055-9965.EPI-07-0236

[32] Wang J, Joshi AD, Corral R, Siegmund KD, Marchand L Le, Martinez ME, et al. Carcinogen metabolism genes, red meat and poultry intake, and colorectal cancer risk. Int $\mathrm{J}$ Cancer 2012; 130(8): 1898-907.

http://dx.doi.org/10.1002/ijc.26199

[33] Koutros S, Andreotti G, Berndt SI, Hughes Barry K, Lubin JH, Hoppin JA, et al. Xenobiotic-metabolizing gene variants, pesticide use, and the risk of prostate cancer. Pharmacogenet Genomics 2011; 21(10): 615-23. http://dx.doi.org/10.1097/FPC.0b013e3283493a57

[34] Skjelbred CF, Saebø M, Hjartåker A, Grotmol T, Hansteen I$\mathrm{L}$, Tveit $\mathrm{KM}$, et al. Meat, vegetables and genetic polymorphisms and the risk of colorectal carcinomas and adenomas. BMC Cancer 2007; 7: 228.

http://dx.doi.org/10.1186/1471-2407-7-228

[35] Eichholzer M, Rohrmann S, Barbir A, Hermann S, Teucher B, Kaaks $\mathrm{R}$, et al. Polymorphisms in heterocyclic aromatic amines metabolism-related genes are associated with colorectal adenoma risk. Int $\mathrm{J}$ Mol Epidemiol Genet 2012; 3(2): 96-106.

[36] Lin J, Forman MR, Wang J, Grossman HB, Chen M, Dinney $\mathrm{CP}$, et al. Intake of red meat and heterocyclic amines, metabolic pathway genes and bladder cancer risk. Int J Cancer 2012; 131(8): 1892-903.

http://dx.doi.org/10.1002/ijc.27437

[37] Wright JL, Neuhouser ML, Lin DW, Kwon EM, Feng Z, Ostrander EA, et al. AMACR polymorphisms, dietary intake of red meat and dairy and prostate cancer risk. Prostate 2011; 71(5): 498-506.

http://dx.doi.org/10.1002/pros.21267

[38] Chen M, Cassidy A, Gu J, Delclos GL, Zhen F, Yang H, et al. Genetic variations in PI3K-AKT-mTOR pathway and bladder cancer risk. Carcinogenesis 2009; 30(12): 2047-52.

http://dx.doi.org/10.1093/carcin/bgp258

[39] Food, Nutrition, Physical Activity, and the Prevention of Cancer: a Global Perspective [Internet]. [cited 2013 Mar 14]. Available from: http: //eprints.ucl.ac.uk/4841/1/4841.pdf

[40] Cross AJ, Ferrucci LM, Risch A, Graubard BI, Ward MH, Park $\mathrm{Y}$, et al. A large prospective study of meat consumption and colorectal cancer risk: an investigation of potential mechanisms underlying this association. Cancer Res 2010; 70(6): 2406-14.

http://dx.doi.org/10.1158/0008-5472.CAN-09-3929

[41] Aune D, De Stefani E, Ronco A, Boffetta P, Deneo-Pellegrini $\mathrm{H}$, Acosta $\mathrm{G}$, et al. Meat consumption and cancer risk: a case-control study in Uruguay. Asian Pac J Cancer Prev 2009; 10(3): 429-36.
[42] De Stefani E, Ronco AL, Boffetta P, Deneo-Pellegrini $H$, Correa P, Acosta G, et al. Nutrient-derived dietary patterns and risk of colorectal cancer: a factor analysis in Uruguay. Asian Pac J Cancer Prev: APJCP 2012; 13(1): 231-5. http://dx.doi.org/10.7314/APJCP.2012.13.1.231

[43] Takachi R, Tsubono $\mathrm{Y}$, Baba K, Inoue M, Sasazuki S, Iwasaki $\mathrm{M}$, et al. Red meat intake may increase the risk of colon cancer in Japanese, a population with relatively low red meat consumption. Asia Pac J Clin Nutr 2011; 20(4): 603-12.

[44] Takata Y, Shu X-O, Gao Y-T, Li H, Zhang X, Gao J, et al. Red meat and poultry intakes and risk of total and causespecific mortality: results from cohort studies of chinese adults in shanghai. PloS One 2013; 8(2): e56963. http://dx.doi.org/10.1371/journal.pone.0056963

[45] Pancione M, Remo A, Colantuoni V. Genetic and epigenetic events generate multiple pathways in colorectal cancer progression. Patholog Res Int 2012; 2012: 509348.

[46] Kang GH. Four molecular subtypes of colorectal cancer and their precursor lesions. Arch Pathol Lab Med 2011; 135(6): 698-703.

[47] Norat T, Bingham S, Ferrari P, Slimani N, Jenab M, Mazuir $\mathrm{M}$, et al. Meat, fish, and colorectal cancer risk: the European Prospective Investigation into cancer and nutrition. J Natl Cancer Inst 2005; 97(12): 906-16. http://dx.doi.org/10.1093/jnci/dji164

[48] Brevik A, Joshi AD, Corral R, Onland-Moret NC, Siegmund $K D$, Le Marchand L, et al. Polymorphisms in base excision repair genes as colorectal cancer risk factors and modifiers of the effect of diets high in red meat. Cancer Epidemiol Biomarkers Prev 2010; 19(12): 3167-73. http://dx.doi.org/10.1158/1055-9965.EPI-10-0606

[49] Sandhu MS, White IR, Mcpherson K. Systematic review of the prospective cohort studies on meat consumption and colorectal cancer risk: a meta-analytical approach. Cancer Epidemiol Biomarkers Prev 10(5): 439-46.

[50] Ferrucci LM, Cross AJ, Graubard BI, Brinton LA, McCarty $\mathrm{CA}$, Ziegler RG, et al. Intake of meat, meat mutagens, and iron and the risk of breast cancer in the prostate, lung, colorectal, and ovarian cancer screening trial. $\mathrm{Br} \mathrm{J}$ Cancer 2009; 101(1): 178-84. http://dx.doi.org/10.1038/sj.bjc.6605118

[51] Fu Z, Deming SL, Fair AM, Shrubsole MJ, Wujcik DM, Shu $\mathrm{X}-\mathrm{O}$, et al. Well-done meat intake and meat-derived mutagen exposures in relation to breast cancer risk: the Nashville Breast Health Study. Breast Cancer Res Treat 2011; 129(3): 919-28.

http://dx.doi.org/10.1007/s10549-011-1538-7

[52] Lima FEL de, Latorre M do RD de O, Costa MJ de C, Fisberg RM. Diet and cancer in Northeast Brazil: evaluation of eating habits and food group consumption in relation to breast cancer. Cad Saude Publica 2008; 24(4): 820-8.

\section{http://dx.doi.org/10.1590/S0102-311X2008000400012}

[53] Ronco AL, De Stefani E, Deneo-Pellegrini H. Risk factors for premenopausal breast cancer: a case-control study in Uruguay. Asian Pac J Cancer Prev 2012; 13(6): 2879-86. http://dx.doi.org/10.7314/APJCP.2012.13.6.2879

[54] Punnen S, Hardin J, Cheng I, Klein EA, Witte JS. Impact of meat consumption, preparation, and mutagens on aggressive prostate cancer. PloS One 2011; 6(11): e27711. http://dx.doi.org/10.1371/journal.pone.0027711

[55] John EM, Stern MC, Sinha R, Koo J. Meat consumption, cooking practices, meat mutagens, and risk of prostate cancer. Nutr Cancer 2011; 63(4): 525-37. http://dx.doi.org/10.1080/01635581.2011.539311

[56] Amin M, Jeyaganth S, Fahmy N, Bégin LR, Aronson S, Jacobson $\mathrm{S}$, et al. Dietary habits and prostate cancer detection: a case-control study. Can Urol Assoc J 2008; 2(5): 510-5 
[57] Sinha R, Park Y, Graubard BI, Leitzmann MF, Hollenbeck A, Schatzkin $A$, et al. Meat and meat-related compounds and risk of prostate cancer in a large prospective cohort study in the United States. Am J Epidemiol 2009; 170(9): 1165-77. http://dx.doi.org/10.1093/aje/kwp280

[58] Keszei AP, Schouten LJ, Goldbohm RA, Van den Brandt PA. Red and processed meat consumption and the risk of esophageal and gastric cancer subtypes in The Netherlands Cohort Study. Ann Oncol 2012; 23(9): 2319-26. http://dx.doi.org/10.1093/annonc/mdr615

[59] Cross AJ, Freedman ND, Ren J, Ward MH, Hollenbeck AR, Schatzkin A, et al. Meat consumption and risk of esophageal and gastric cancer in a large prospective study. Am J Gastroenterol 2011; 106(3): 432-42. http://dx.doi.org/10.1038/ajg.2010.415

[60] O'Doherty MG, Cantwell MM, Murray LJ, Anderson LA, Abnet CC. Dietary fat and meat intakes and risk of reflux esophagitis, Barrett's esophagus and esophageal adenocarcinoma. Int J Cancer 2011; 129(6): 1493-502. http://dx.doi.org/10.1002/ijc.26108

[61] De Stefani E, Ronco AL, Boffetta P, Deneo-Pellegrini $H$, Acosta G, Mendilaharsu M. Meat consumption, meat cooking and risk of lung cancer among Uruguayan men. Asian Pac J Cancer Prev: APJCP 2010; 11(6): 1713-7.

[62] Lam TK, Cross AJ, Consonni D, Randi G, Bagnardi V, Bertazzi PA, et al. Intakes of red meat, processed meat, and meat mutagens increase lung cancer risk. Cancer Res 2009; 69(3): 932-9. http://dx.doi.org/10.1158/0008-5472.CAN-08-3162

[63] Tasevska N, Sinha R, Kipnis V, Subar AF, Leitzmann MF, Hollenbeck AR, et al. A prospective study of meat, cooking methods, meat mutagens, heme iron, and lung cancer risks. Am J Clin Nutr 2009; 89(6): 1884-94. http://dx.doi.org/10.3945/ajcn.2008.27272

[64] Linos E, Willett W. Meat, dairy, and breast cancer: do we have an answer? 1, 2 2009; 455-6.

[65] Hessels D, Verhaegh GW, Schalken JA, Witjes JA. Applicability of biomarkers in the early diagnosis of prostate cancer. Expert Rev Mol Diagn 2004; 4(4): 513-26. http://dx.doi.org/10.1586/14737159.4.4.513

[66] Kumar-Sinha C, Shah RB, Laxman B, Tomlins SA, Harwood $\mathrm{J}$, Schmitz W, et al. Elevated alpha-methylacyl-CoA racemase enzymatic activity in prostate cancer. Am J Pathol 2004; 164(3): 787-93. http://dx.doi.org/10.1016/S0002-9440(10)63167-7
[67] Isa F, Xie L-P, Hu Z, Zhong Z, Hemelt M, Reulen RC, et al. Dietary consumption and diet diversity and risk of developing bladder cancer: results from the South and East China casecontrol study. Cancer Causes Control: CCC 2013.

[68] Wu JW, Cross AJ, Baris D, Ward MH, Karagas MR, Johnson $A$, et al. Dietary intake of meat, fruits, vegetables, and selective micronutrients and risk of bladder cancer in the New England region of the United States. Br J Cancer 2012; 106(11): 1891-8. http://dx.doi.org/10.1038/bjc.2012.187

[69] Chan JM, Gong Z, Holly EA, Bracci PM. Dietary patterns and risk of pancreatic cancer in a large population-based casecontrol study in the san francisco bay area. Nutr Cancer 2013; 65(1): 157-64 http://dx.doi.org/10.1080/01635581.2012.725502

[70] Chuang S-C, Jenab M, Heck JE, Bosetti C, Talamini R, Matsuo $\mathrm{K}$, et al. Diet and the risk of head and neck cancer: a pooled analysis in the INHANCE consortium. Cancer Causes Control: CCC 2012; 23(1): 69-88. http://dx.doi.org/10.1007/s10552-011-9857-x

[71] Lagiou $P$, Talamini $R$, Samoli E, Lagiou A, Ahrens W Pohlabeln $\mathrm{H}$, et al. Diet and upper-aerodigestive tract cancer in Europe: the ARCAGE study. Int J Cancer 2009; 124(11): 2671-6. http://dx.doi.org/10.1002/ijc.24246

[72] Kallianpur AR, Lee S-A, Xu W-H, Zheng W, Gao Y-T, Cai H et al. Dietary iron intake and risk of endometrial cancer: a population-based case-control study in Shanghai, China. Nutr Cancer 2010; 62(1): 40-50. http://dx.doi.org/10.1080/01635580903191544

[73] Jiménez-Colmenero F, Carballo J, Cofrades S. Healthier meat and meat products: their role as functional foods. Meat Sci 2001; 59(1): 5-13. http://dx.doi.org/10.1016/S0309-1740(01)00053-5

[74] Sesink AL, Termont DS, Kleibeuker JH, Van der Meer R. Red meat and colon cancer: dietary haem-induced colonic cytotoxicity and epithelial hyperproliferation are inhibited by calcium. Carcinogenesis 2001; 22(10): 1653-9. http://dx.doi.org/10.1093/carcin/22.10.1653

[75] Marianski S, Mariański A, Marianski R. Meat Smoking and Smokehouse Design. Bookmagic LLC 2009; p. 317. 